\title{
Sustainability Analysis of Beef Cattle Farm Business in Langsa Baro Subdistrict, Langsa City
}

\author{
R Mastuti*, Nurhaliza, F H Saragih, Muslimah, M Fuad \\ Samudra University \\ Langsa City, Indonesia \\ *rinimastuti@unsam.ac.id
}

\begin{abstract}
This study aims to analyse the sustainability of beef cattle farming business in Langsa Baro Subdistrict, Langsa City. The location of the study was determined deliberately (purposive sampling) with the consideration that Langsa Baro Subdistrict is the sub-district with the largest number of farmer groups in Langsa City. The scope of this research is based on 4 aspects, namely economic aspects, ecological aspects, socio-cultural aspects, and aspects of cultivation conditions. The results showed the sustainability value of beef cattle farming in Langsa Baro Subdistrict, Langsa City with the percentage of farmers who have a sustainability value of $16-20$ by $13 \%$ and farmers who have a sustainability value of $11-15$ by $87 \%$. This means that as many as $87 \%$ of farmers have a beef cattle farming business with moderate sustainability criteria and as many as $13 \%$ of farmers have a beef cattle farming business with very sustainable criteria (very sustainability).
\end{abstract}

Keywords—sustainability, farm business, beef cattle

\section{INTRODUCTION}

Indonesia is currently one of the countries facing the Covid-19 outbreak. Agriculture is one of the sectors of the economy that is expected to be able to be the leading sector to strengthen and restore the people's economy, because this sector is minimal impact of the covid-19 outbreak [1]. In agriculture, subsectors of farms have a strategic role as an effort to strengthen food security to meet the needs of animal proteins, empower the community economy and spur regional development [2].

One form of livestock business that has great potential to be developed is beef cattle. In order to improve the welfare of farmers and realize food independence of animal origin, the Ministry of Agriculture launched a special effort program of Mandatory Inducted Cattle Pregnant (UPSUS SIWAB) by optimizing the potential of inductees to produce good quality cattle and increase the population. One of the regencies/cities located in Aceh Province that also runs the Upsus Siwab (Sapi Wajib Bunting) is Langsa City. The program started in 2017 and is already running well. Upsus Siwab is an effort to accelerate the increase of cattle population in order to support the national resilience program, with the hope of increasing the livestock population with the birth of good quality pedet so as to increase the income and welfare of farmers [3].

Currently, the management of livestock business in Langsa City has shown improvement with the traditional livestock keeping through extensive and semi-extensive grazing patterns as well as by conducting artificial insemination (IB) on beef cattle inductees. Beef cattle business has long been done by farmers, especially in Langsa Baro Subdistrict, but until now there has been no research on the sustainability of beef cattle farming business. The sustainability of a business can be analysed through various aspects such as agronomic aspects, economic aspects, socio-cultural aspects and ecological aspects $[4,5]$ and technological aspects [6].

In this study the aspects that researchers used to analyse the sustainability of beef cattle farming business include economic aspects, ecological aspects, socio-cultural aspects, and aspects of cultural conditions. This needs to be done, considering the importance of analysis of the sustainability of beef cattle farming business in helping farmers to make informed decisions in managing existing resources efficiently and effectively. Based on the problems and theories stated above, this study aims to analyse the sustainability of beef cattle farming in Langsa Baro Subdistrict, Langsa City. Based on the problems and theories stated above, this study aims to analyse the sustainability of beef cattle farming in Langsa Baro Subdistrict, Langsa City.

\section{RESEARCH METHODS}

This research was conducted in January 2021 in Langsa City. The location of the research is in Langsa Baro Subdistrict. Determination of the location is determined deliberately (purposive sampling) because Langsa Baro subdistrict is the district with the largest number of farmer groups in Langsa City.

The method used in this study is descriptive quantitative, which is to give an overview and descriptive income obtained by farmers and know how the sustainability of the prospects of beef cattle farming business in Langsa Baro Subdistrict, Langsa City. 
The population in this study is all beef cattle farmers in Langsa Baro Subdistrict Langsa City with a population of 254 beef cattle farmers. The population of beef cattle farmers is heterogeneous, namely the number of beef cattle owned by farmers are different, so to homogenize it is stratified (stratified) that is the population is divided into several stratums based on business groupings namely [7] :

- Stratum A with a small business scale or a scale of one (1-5 cattle) as many as 225 farmers.

- Stratum B with medium business scale or scale of two (6-10 cattle) as many as 24 farmers

- Stratum C with a large scale or a scale of three $(>10$ cattle) as many as 5 farmers.

From the number of populations then conducted a minimum sampling that can represent the population by using the formula Slovin [8] :

$$
n=\frac{N}{1+N(e)^{2}}
$$

Description:

n : Number of samples

$N \quad$ : Population

e $\quad$ : Leniency rate $(20 \%)$

In slovin formula there is a condition that the value $\mathrm{e}=0.1$ $(10 \%)$ for a large population and the value $e=0.2(20 \%)$ for a small population. So, the range of samples that can be taken from the Slovin technique is between $10-20 \%$ of the research population. In this study the level of looseness used is $20 \%$, so that the number of samples obtained as much as:

$$
\begin{gathered}
n=\frac{254}{1+254(20 \%)^{2}} \\
n=\frac{254}{1+254(0,04)} \\
n=\frac{254}{1+10,16} \\
n=\frac{254}{11,16} \\
n=22,7598=23 \text { farmers. }
\end{gathered}
$$

Sampling in each stratum is done by disproportionate stratified random sampling technique, where the technique is performed when the population has elements that are not homogeneous and disproportionately proportional [8]. So that the number of samples per stratum obtained:

- Stratum A : $\mathrm{Sa}=225 \times 5 \%=11.25=11$ farmers

- Stratum B : $\mathrm{Sb}=24 \times 30 \%=7.2=7$ farmers.
- Stratum $\mathrm{C}: \mathrm{Sc}=5$ farmers (researchers take all farmers because the number of farmers in this stratum is relatively small).

The data sources in this study are primary and secondary data. Primary data in the form of data sourced from observations and direct interviews with beef cattle farmers, while secondary data is processed data obtained from relevant agencies such as the Central Bureau of Statistics Langsa city as well as the Department of Food, Agriculture, Marine and Fisheries Langsa city as well as other sources related to research based on existing literature.

The sustainability analysis of beef cattle farming can be determined by summing the average value of each aspect indicator obtained [4].

$$
\mathrm{ST}=\mathrm{KE}+\mathrm{KEK}+\mathrm{KSB}+\mathrm{KKB}
$$

Description:

$$
\begin{aligned}
& \mathrm{ST}=\text { Sustainability } \\
& \mathrm{KE}=\text { Economic sustainability } \\
& \mathrm{KEK}=\text { Ecological sustainability } \\
& \mathrm{KSB}=\text { Socio-cultural sustainability } \\
& \mathrm{KKB}=\text { Sustainability of cultivation conditions }
\end{aligned}
$$

There are three criteria in the calculation, namely:

- If the value of ST $=4-10$ means the beef cattle farming business is not sustainable (not sustainability).

- If the value of ST =11-15 means the beef cattle farming business is medium sustainability (moderate sustainability).

- If the value of ST = 16-20 means beef cattle farming business is very sustainable (very sustainability).

Sustainability of economic aspects is determined based on several indicators, namely profit (profit) in the cultivation of beef cattle through the analysis of $\mathrm{B} / \mathrm{C}$ ratio, how to sell / market livestock products, prices of livestock commodities and subsidies from the government in the form of cattle.

Sustainability of ecological aspects is determined based on several indicators, namely the state of agroclibility, feed support capacity in the form of forage acquisition, type of animal feed, availability of land for animal feed, utilization of livestock waste for organic fertilizer, availability of slaughterhouses (RPH) around the farm site and the distance of farm business locations with residential areas.

The sustainability of socio-cultural aspects is determined based on several indicators, namely the participation of others in livestock business, the status of livestock ownership, the status of land ownership, the allocation of time for livestock business, the role of the community in the management of cattle business. 
The sustainability of aspects of cultivation conditions is determined based on several indicators, namely the procurement of livestock seedlings, the level of disease attack, the level of pest and disease control and the death rate of livestock / year.

\section{RESULTS AND DISCUSSION}

\section{A. Sustainability Based on Economic Aspects}

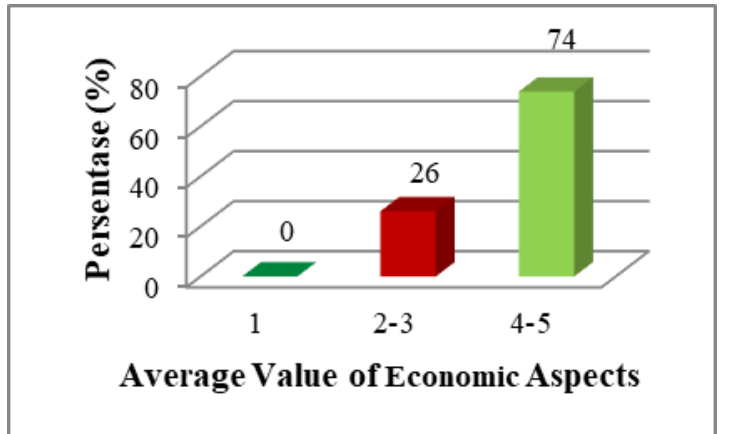

Fig. 1. Average value of economic aspects (Primary data analysis).

In figure 1 , it appears that as many as $74 \%$ of respondents have an average economic aspect value of 4-5 so that it can be categorized as very sustainable (very sustainability) and as many as $26 \%$ of farmers have an average value of economic aspects 2-3 so that it is also categorized with moderate sustainability. Based on the results of interviews with farmers respondents, in the economic aspect there are several indicators that contribute the highest value, namely through the analysis of $\mathrm{B} / \mathrm{C}$ ratio with the average range of values obtained ranging from 4-5 and how to sell / market livestock products are relatively easy. It is said to be easy because the average price of an adult cow (> 2 years) is affordable which ranges from $\mathrm{Rp}$ 14,000,000-16,000,000 for Aceh cattle compared to other types of cattle. These cows are usually marketed at the time of Islamic holidays, at that time the demand for beef cattle by consumers becomes high so many buyers come to farmers so that farmers do not have to look for buyers of beef cattle in particular.

\section{B. Sustainability Based on Ecological Aspects}

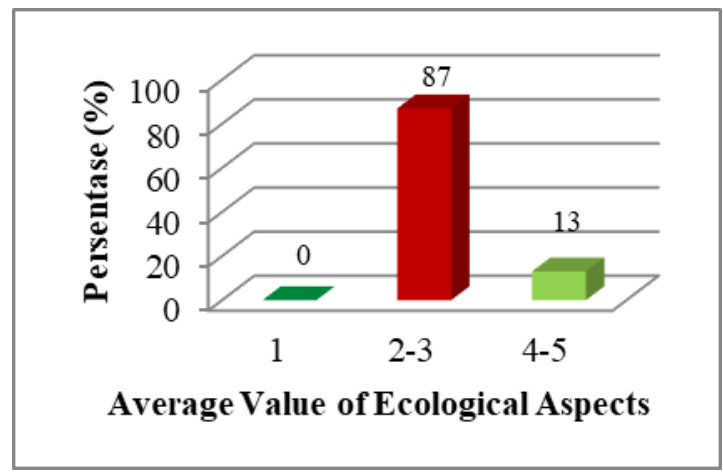

Fig. 2. Average value of ecological aspects (Primary data analysis).
In figure 2, it appears that as many as $87 \%$ of beef cattle farmers have an average value of ecological aspects 2-3 so that it is categorized as moderate sustainability and as much as $13 \%$ of beef cattle farmers have an average value of ecological aspects 4-5 so that it is also categorized as very sustainable (very sustainability). In the ecological aspect of the existence of feed for livestock greatly affects the sustainability of livestock business. This is in accordance with the research conducted by Bahrun et al [9], input of beef cattle production. But the fact is that most of the respondent farmers do not have their own land for forage feed for livestock, they tend to get feed from natural grass that grows by itself in empty field lands. This is what makes the ecological aspect of sustainability category moderate (sustainability).

\section{Sustainability Based on Socio-Cultural Aspects}

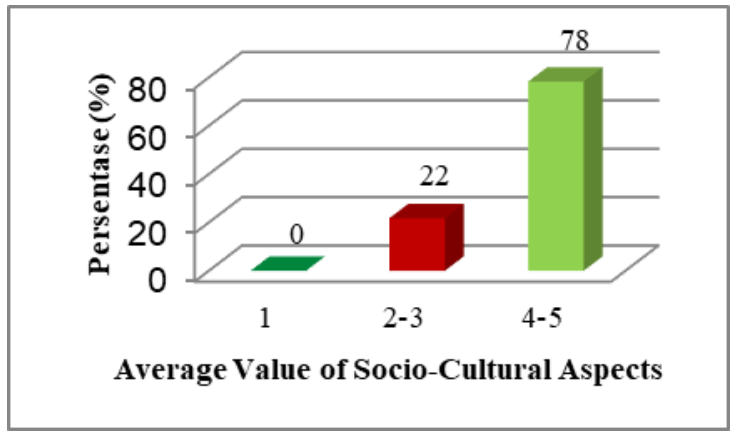

Fig. 3. Average value of socio-cultural aspects (Primary data analysis).

In figure 3 , it appears that as many as $78 \%$ of beef cattle farmers have an average value of social aspects of busaya 4-5 so that it is categorized as very sustainable (very sustainability) and as many as $22 \%$ beef cattle farmers have an average value of economic aspects 2-3 so that it is also categorized as moderate sustainability. In the socio-cultural aspect that has the highest value contribution, namely the allocation of time for livestock business and the role of the community in the management of cattle business. The amount of working time allocated by farmers for cattle businesses is measured in hours. Allocation of working hours in the form of taking forage, feeding and drinking and moving cows (releasing and picking up cows to return to the cage) is usually done about 6 hours in a day from $12 \mathrm{pm}$ to $06 \mathrm{pm}$. Breeding beef cattle is a side job for most of the respondent farmers so that they manage their business on a part-time basis and their main jobs such as farmers, day laborers, woodworkers, teachers, students, selfemployed and traders. 


\section{Sustainability Based on Aspects of Cultivation Conditions}

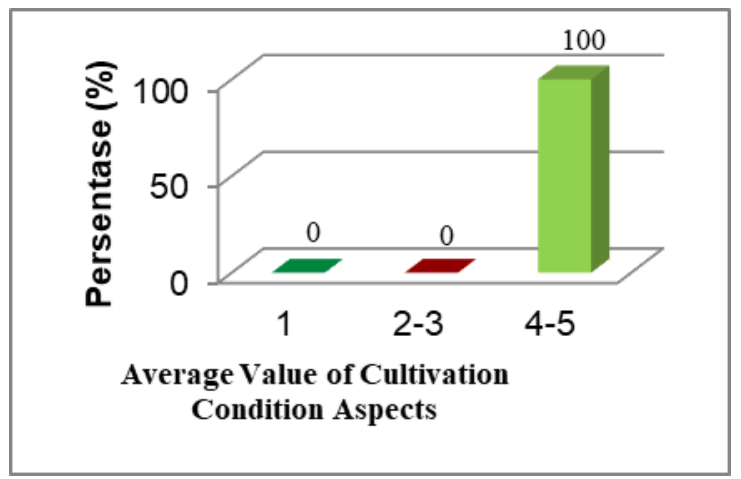

Fig. 4. Average value of aspects of cultivation conditions (Primary data analysis).

Figure 4 shows that in the aspect of cultivation conditions of all respondent farmers, namely $100 \%$ beef cattle farmers in doing their business can be said to be very sustainable (very sustainability) seen from the social aspect of cultivation with a value of 4-5. This means that in the aspect of cultivation conditions, the sustainability of beef cattle business does not cause problems. In terms of cultivation conditions, the provision of vitamins and medicines for livestock becomes one of the important factors in the sustainability of cattle business so that cattle are not susceptible to pests and diseases that can cause livestock to grow thin even in more severe attacks livestock can die. It is also inseparable from the activities of farmers in disengaged livestock cages every day.

\section{E. Sustainability of Beef Cattle Farming Business}

Sustainability value (ST) is the average value obtained from the summation of the average value of sustainability of economic aspects (KE), sustainability of ecological aspects (KEK), sustainability of socio-cultural aspects (KSB) and sustainability aspects of cultivation conditions (KKB).

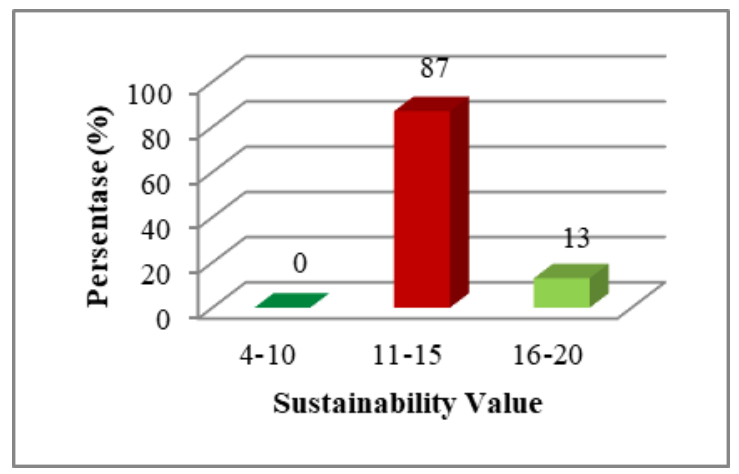

Fig. 5. Value of sustainability (Primary data analysis).

Figure 5 shows the sustainability value of beef cattle farming in Langsa Baro Subdistrict, Langsa City with the percentage of farmers who have a sustainability value of 16-20 of $13 \%$ and farmers who have a sustainability value of $11-15$ of $87 \%$. This means that as many as $87 \%$ of farmers have a beef cattle farming business with moderate sustainability criteria and as many as $13 \%$ of farmers have a beef cattle farming business with very sustainable criteria (very sustainability).

In this study, the sustainability of beef cattle farming business as a whole is influenced greatly by the income received by farmers through the large scale of ownership of the number of cattle that farmers have, the ease in obtaining animal feed in the form of forage and feed reinforcement (concentrates, pulp tofu and sago pulp) as well as the amount of labour costs incurred by farmers.

This is in line with the Jamilah's research [10] that the larger the scale of cattle business run by farmers, the greater the profit / income received by farmers. The scale of livestock ownership business is directly related to income, resulting in the sustainability of the economic aspect. This is also in accordance with the research conducted by Utama [11] and Rusdiana et al [12] explained that if the value of B /C Ratio > 1 means that beef cattle farming business is worth continuing.

Sustainability in the ecological aspect is one of the indicators that have the most value that is related to feed. Otampi et al [13] suggest that feed is an important factor in conducting livestock business. Similarly, with sustainability in the socio-cultural aspects and aspects of cultivation conditions, the participation of family and community roles is urgently needed. This is related to research conducted by Zakaria [14] explaining that the role of the community is needed to ensure sustainability in the management of cattle business.

Therefore, efforts can be made to increase the percentage of farmers who have a beef cattle farming business with moderate sustainability criteria to farmers who have a beef cattle farming business with very sustainable criteria (very sustainability) can be done by increasing income through increasing the scale of business. Darmawi [15] stated that acceptance is everything obtained from a farm product. The more it generates, the greater the revenue it gets. This must be offset by the addition of capital issued by farmers to increase the number of inductees and the addition of pedets through artificial insemination or natural mating. Government policy is needed in providing subsidies and capital loans to farmers and helping the community to make the most of existing natural potential, determining the selling price of cattle to be higher, increasing the area of land for animal feed with the efforts of extenibility and intensification and effectiveness related to land area for the support capacity of animal feed that in the future is predicted to experience a reduction in acreage as the number of residents increases considering the results obtained from breeding beef cattle provide a bright prospect in the future.

\section{CONCLUSION}

Based on the results of research on the sustainability analysis of beef cattle farming in Langsa Baro Subdistrict, Langsa city then the conclusion that can be drawn is in general the level of sustainability of beef cattle farming business in Langsa Baro Subdistrict, Langsa City shows that as many as $87 \%$ of respondent farmers have a beef cattle farming business that is critical of moderate sustainability (moderate 
sustainability) with a sustainability value of $11-15$ and as many as $13 \%$ of respondent farmers have a beef cattle farming business that is very sustainable (very sustainability) with a sustainability value of $16-20$.

\section{REFERENCES}

[1] A.H. Salendu, M.L. Rundengan, T.F. Lumy and D. Polakitan, "Pemberdayaan Kelompok Tani Ternak Sapi di Masa Pandemi," Pros. Semin. Teknol. dan Agribisnis Peternak. VII-Webinar Prospek Peternak. di Era Norm. Baru Pasca Pandemi COVID-19, Fak. Peternak. Univ. Jenderal Soedirman, vol. 6, no. 2, pp. 239-246, 2020.

[2] A. Daryanto, "Peranan Modal Sosial Dalam Pembangunan Peternakan," Trobos, 2011

[3] Y. Yusri, Data Peternakan-Dinas Pertanian Perkebunan dan Peternakan Kota Langsa. Langsa, 2020.

[4] H. Pranoto, M.A. Chozin, H.S. Arifin and E. Santosa, "Analisis karakteristik sosial ekonomi dan keberlanjutan sistem agroforestri di sub Daerah Aliran Sungai Cisokan," Prosiding Seminar Nasional Agroforestri, pp. 625, 2013.

[5] R. Mastuti, Z. Fanani, B.A. Nugroho and H.D. Utami, "Sustainable Analysis in Ecology Dimension of Dairy Cattle for Development of Livestock Area in Batu City Indonesia," IOSR J. Agric. Vet. Sci. Ver. II, vol. 9, no. 7, pp. 2319-2372, 2016.

[6] R. Mastuti, F. Alham, C. Gustiana, H. Hanisah, M. Jamil, M. Muslimah and R. Rozalina, "Sustainability of technological dimension in dairy agribusiness," Journal of Physics: Conference Series, vol. 1375, no. 1, pp. 012043. IOP Publishing.
[7] A.H. Hoddi and M.B. Rombe, Analisis Pendapatan Peternakan Sapi Potong di Kecamatan Tanete Rilau, Kabupaten Barru. Fakultas Peternakan UNHAS, 2011.

[8] S. Sugiono, Metode Penelitan Kuantitatif, kualitatif dan R\&D. Bandung: Alfabeta, 2016

[9] B. Bahrun, T. Widyastuti, N. Hidayat, D.A. Saputra and D.R. Putri, "Daya dukung hijauan rumput alam sebagai pakan ternak sapi potong di BKPH Kebasen, Banyumas," In prosiding seminar teknologi agribisnis peternakan (stap) fakultas peternakan universitas jenderal soedirman, vol. 6, pp. 115-119, 2018.

[10] J. Jamilah, "Analisis Pendapatan Peternak Sapi Aceh," Agrifo: Jurnal Agribisnis Universitas Malikussaleh, vol. 2, no. (2), pp. 50-55, 2017.

[11] B.P. Utama, "Analisis Kelayakan Finansial Usaha Peternakan Sapi Potong," STOCK Peternakan, vol. 2, no. (1), 2020

[12] S. Rusdiana, U. Adiati and R. Hutasoit, "Analisis Ekonomi Usaha Ternak Sapi Potong Berbasis Agroekosistem Di Indonesia," J. Sos. Ekon. dan Kebijak. Pertan., vol. 5, no. 2, 2016

[13] R.S. Otampi, F.H. Elly, M.A. Manese and G.D. Lenzun, "Pengaruh Harga Pakan dan Upah Tenaga Kerja Terhadap Usaha Ternak Sapi Potong Petani Peternak di Desa Wineru Kecamatan Likupang Timur Kabupaten Minahasa Utara," Zootec, vol. 37, no. (2), pp. 483-495, 2017.

[14] A.K. Zakaria, "Kebijakan Pengembangan Budidaya Kedelai Menuju Swasembada Melalui Partisipasi Petani," Anal. Kebijak. Pertan., vol. 8, no. 3, pp. 259-272, 2010.

[15] D. Darmawi, "Pendapatan Usaha Pemeliharaan Sapi Bali di Kabupaten Muaro Jambi," J. Ilm. Ilmu-Ilmu Peternak., vol. XIV, no. 1, pp. 14-22, 2011 